\title{
Antimicrobial Activity of Selected Corticolous Macrolichens
}

\author{
Prashith Kekuda T. $\mathbf{R}^{1,2^{*}}$, Ranjitha M. ${ }^{1}$, Ghazala Firdose ${ }^{1}$, Vidya $P^{1}$ and Vinayaka K. ${ }^{3}$ \\ ${ }^{1}$ Department of Microbiology, S.R.N.M.N College of Applied Sciences, N.E.S campus, Balraj Urs Road, \\ Shivamogga-577201, Karnataka \\ ${ }^{2}$ Department of Microbiology, Sahyadri Science College (Autonomous), Shivamogga-577203, Karnataka \\ ${ }^{3}$ Department of Botany, Kumadvathi First Grade College, Shikaripura, Karnataka
}

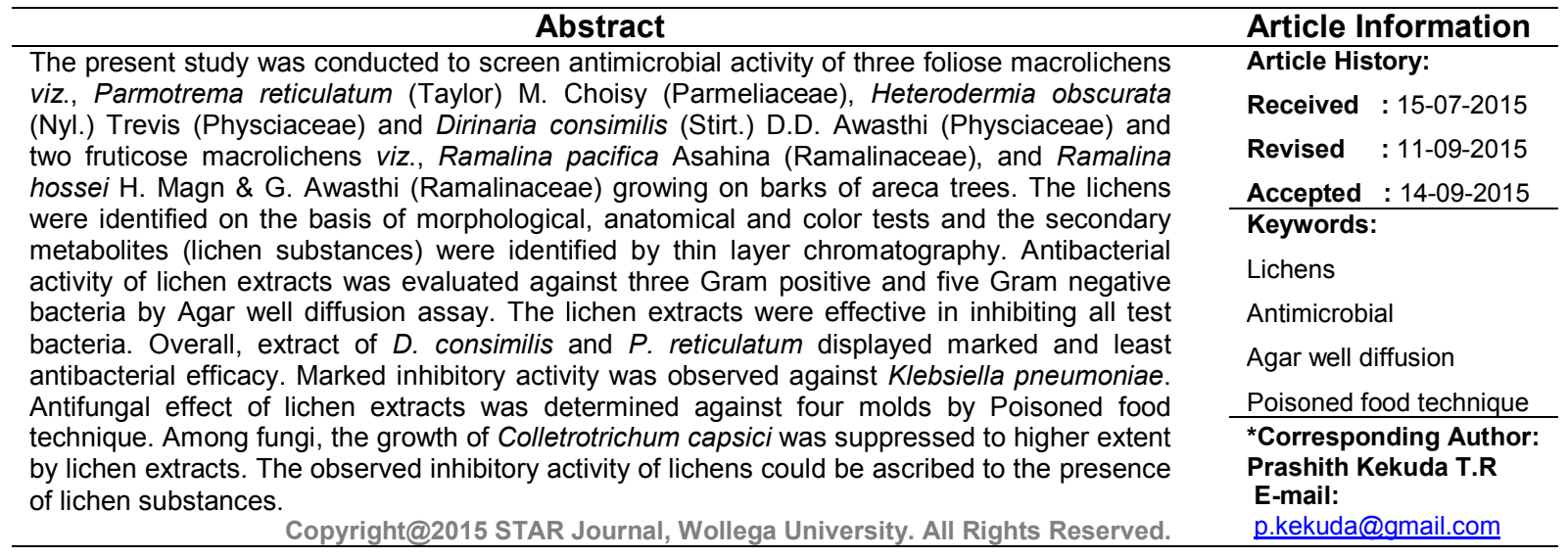

\section{INTRODUCTION}

Lichens are nonvascular cryptogams and represents stable, successful and self-supporting symbiotic relationship between mycobiont (fungus) and photobiont partners (algae/cyanobacteria) which together form an independent physiological unit. The photobiont provides the mycobiont with nutrients by its photosynthetic activity whereas the mycobiont helps in absorption of water and nutrients from surroundings and also provide protection to the photobiont. Out of nearly 80000 fungi reported in nature, approximately $17 \%$ have been lichenized. The fungi that are present in lichens are called lichenized fungi. Vast majority of mycobiont belongs to Ascomycetes. Lichens are omnipresent and are known to occupy every possible ecological niche and can easily cope up with extreme conditions. The lichens are known to be early land colonizers and have a slow growth rate. Lichens occur in various growth forms such as crustose, foliose and fruticose. All over world, lichens are used as medicine, spice and in the manufacture of dyes. Lichens are used in several systems of traditional medicine such as Ayurveda and Unani. Lichens are said to cure dyspepsia, bleeding piles, bronchitis, stomach disorders, scabies and many disorders of blood and heart. Lichens have been considered as indicators of air pollution and are used as biomonitors of atmospheric pollution in different zones. Lichens are also used as food especially during scarcity and famine. The natural thalli of these lichens contain a variety of secondary metabolites (lichen substances) such as depsides, depsidones, dibenzofurans and pulvinic acid which seldom occur in other organisms. These metabolites are predominantly produced by mycobiont. Lichen extracts containing usnic acid have been utilized for medicinal, perfumery, cosmetic and other applications. Usnic acid is formulated in creams, toothpaste, mouthwash, deodorants and sunscreen products. Lichen extracts and the secondary metabolites are known to exhibit a number of bioactivities such as antioxidant, antimicrobial, antimycobacterial, antiviral, antiinflammatory, antioxidative, analgesic, antipyretic, antiproliferative, insecticidal, anthelmintic, and cytotoxic effects (Nayaka et al., 2007; Upreti and Nayaka, 2008; Vinayaka et al., 2009; Hoskeri et al., 2010; Verma et al., 2012; Zambare and Christopher, 2012; Kekuda et al., 2012; Ghate et al., 2013; Upreti et al., 2013; Balaji and Hariharan, 2013; Shukla et al., 2014; Kambar et al., 2014a).

Lichens grow on various substrates such as barks (corticolous), rocks (saxicolous), leaves (follicolous), moss (muscicolous) and soils (terricolous) and manmade substrates like iron, cloth, glass, leather which provides relative performance and surface stability. Most lichen taxa are substrate specific while few can grow on a variety of substrates. Lichens growing on the barks of tress are known as corticolous lichens. In India, $>70 \%$ lichens are corticolous (Nayaka et al., 2007; Kambar et al., 2014a). Barks of a number of trees support the growth of epiphytic lichens (Rambo, 2010; Rout et al., 2012; Kambar et al., 
Prashith Kekuda et al.,

2014a; Dudani et al., 2015). Areca catechu (betel nut) is grown widely in southern India. The nature and texture of bark of areca seems to be suitable for the luxuriant growth of lichens (Nayaka et al., 2006). In the present study, we carried out antimicrobial activity of three foliose macrolichens viz., Parmotrema reticulatum (Taylor) M. Choisy (Parmeliaceae), Heterodermia obscurata (Nyl.) Trevis (Physciaceae), Dirinaria consimilis (Stirt.) D.D. Awasthi (Physciaceae) and two fruticose lichens viz., Ramalina pacifica Asahina (Ramalinaceae), and Ramalina hossei H. Magn \& G. Awasthi (Ramalinaceae) growing on barks of areca trees.

\section{MATERIALS AND METHODS}

\section{Collection and Identification of Lichens}

The lichens viz., $D$. consimilis, $R$. hossei, $R$. pacifica, $P$. reticulatum and $H$. obscurata grown on the barks of areca trees were collected in and around Tarikere, Chikkamagaluru district, Karnataka during January 2015. The collected lichens were identified on the basis of morphological, anatomical and color tests. Morphological characters were studied under dissection microscope. Color tests were done by spot tests using chemical reagents viz., aqueous potassium hydroxide $(K)$, Steiner's stable paraphenylinediamine $(P)$ and aqueous calcium hypochlorite $(\mathrm{C})$. Secondary metabolites were detected by thin layer chromatography using solvent system A (Culberson and Kristinsson, 1970; Culberson, 1972; Walker and James, 1980; Awasthi, 2000).

\section{Extraction}

The lichens were powdered in a blender. A known quantity $(10 \mathrm{~g})$ of each lichen material was subjected to maceration process. The powder was immersed in $100 \mathrm{ml}$ of methanol and left for 48 hours with occasional stirrings. The content of flask was filtered through muslin cloth followed by Whatman no. 1 filter paper. The filtrates were evaporated to dryness and used for bioactivity determinations (Kambar et al., 2014a).

\section{Antibacterial Activity of Lichen Extracts}

The inhibitory efficacy of extracts of selected lichens against test bacteria (Gram positive bacteria viz.,
Sci. Technol. Arts Res. J., July-Sep 2015, 4(3): 169-174

Staphylococcus aureus, Bacillus subtilis and B. coagulans and Gram negative bacteria viz., Klebsiella pneumoniae, Salmonella typhi, Pseudomonas aeruginosa, Escherichia coli and Ralstonia solanacearum) was tested by Agar well diffusion method. 24 hours old Nutrient broth cultures of test bacteria were swabbed uniformly on sterile Nutrient agar plates. Wells of $8 \mathrm{~mm}$ diameter were punched in the inoculated plates using sterile cork borer. Using sterile pipettes, lichen extracts $(20 \mathrm{mg} / \mathrm{ml}$ of $25 \%$ Dimethyl sulfoxide [DMSO]), standard antibiotic (Chloramphenicol, $1 \mathrm{mg} / \mathrm{ml}$ of sterile distilled water) and DMSO (25\%, in sterile distilled water) were dispensed into labeled wells. The plates were incubated in upright position for 24 hours at $37^{\circ} \mathrm{C}$. The zones of inhibition were measured using a ruler (Kambar et al., 2014a).

\section{Antifungal Activity of Lichen Extracts}

The antifungal potential of extract of selected lichens was evaluated by Poisoned food technique against fungi namely Colletotrichum capsici (isolate from anthracnose of chilli), Fusarium oxysporum f.sp. zingiberi (isolate from rhizome rot of ginger) and Alternaria alternata and Aspergillus flavus (isolates from moldy grains of sorghum). The control and poisoned $(0.5 \mathrm{mg}$ extract $/ \mathrm{ml}$ of medium) Potato dextrose agar plates were aseptically inoculated at the centre of plates by point inoculation technique. The plates were incubated in upright position for 72 hours at room temperature. The diameter of fungal colonies in mutual perpendicular directions was measured using a ruler. Antifungal activity (in terms of inhibition of growth) was calculated using the formula:

Inhibition of mycelial growth $(\%)=(C-T / C) \times 100$, where $\mathrm{C}$ and $\mathrm{T}$ refers to diameter of fungal colonies on control and poisoned plates respectively (Kambar et al., 2014a).

\section{RESULTS AND DISCUSSION}

\section{Characteristics of Lichens Selected}

The result of color tests and the secondary metabolites (as detected by TLC) of selected lichens is shown in Table 1.

Table 1: Result of color tests and secondary metabolites of lichens

\begin{tabular}{lll}
\hline \multicolumn{1}{c}{ Name } & \multicolumn{1}{c}{ Color test } & \multicolumn{1}{c}{ Secondary metabolites } \\
\hline P. reticulatum & Cortex K+ yellow, C-, KC-, P+ yellow; & Medulla K+ yellow turning deep red, C-, KC-, P+ orange \\
& Cortex K+ yellow C-, KC-, P+ yellow; & Salazinic acid, Consalazinic acid \\
H. obscurata & Medulla K-, C-, KC-, P- & Atranorin, Chloroatranorin, Zeorin \\
R. pacifica & Medulla K-, C- & Usnic acid, Salazinic acid \\
D. consimilis & Cortex K+ yellow, C-, KC-, P+ yellow; Medulla K-, & Atranorin, Chloroatranorin, Sekikaic acid \\
R. hossei & C-, KC-, P- & Usnic acid, sekikaic acid \\
\hline
\end{tabular}

\section{Antibacterial Activity of Lichen Extracts}

The discovery of antibiotics is considered as one the major milestones in chemotherapy and represents a fundamental triumph of science of medicine. However, the indiscriminate use of these antibiotics resulted in the emergence of resistant pathogens. The prevalence of these resistant bacterial strains increased in various countries. Antibiotics such as penicillins, cephalosporins and aminoglycosides are no longer effective against certain pathogenic bacteria. The resistance development increases the potential of bacteria to cause diseases and poses a serious challenge to health. This also increases morbidity and mortality and the costs for the treatment. The natural products derived from animals, plants and microorganisms have been considered as suitable alternatives to antibiotics (Chait et al., 2012; Chaves et al., 2015). Lichens appear to be promising resources of bioactive compounds having activity against many pathogens. It is shown that lichen extracts and their compounds exhibit antimicrobial activity. The secondary metabolites of lichens are shown to possess antimicrobial activity. Atranorin (Yilmaz et al., 2004; Verma et al., 2011), Chloroatranorin (Turk et al., 2006), Lecanoric acid (Verma et al., 2011), Usnic acid (Yilmaz et al., 2004) and 
Prashith Kekuda et alo,

Protolichesterinic acid (Ingolfsdottir et al., 1997; Turk et al., 2003) were shown to exhibit antimicrobial activity.

In the present study, we evaluated the inhibitory effect of selected lichens against Gram positive and Gram negative bacteria by Agar well diffusion assay. The result of antibacterial effect is shown in Table 2 and Figure 1. All lichens were effective in inhibiting test bacteria as evidenced by the presence of zones of inhibition around wells. However, the antibacterial effect observed varied among lichens. Overall, extract of $D$. consimilis and $R$. pacifica exhibited marked antibacterial activity. Least inhibitory effect was observed in case of $P$. reticulatum. Among bacteria, $K$. pneumoniae was inhibited to high extent. Reference antibiotic caused higher inhibition of test bacteria when compared to lichen extracts. DMSO (vehicle) did not cause inhibition of test bacteria. The efficacy of lichens to inhibit bacteria is demonstrated by several researchers. The solvent extracts of $R$. pacifica
Sci. Technol. Arts Res. J., July-Sep 2015, 4(3): 169-174

were shown to exhibit inhibitory activity against multiresistant bacterial strains (Hoskeri et al., 2010). Extract of Everniastrum cirrhatum was shown to inhibit the growth of Gram positive and Gram negative bacteria (Swathi et al., 2010). Parmotrema nilgherrense was shown to possess inhibitory activity against drug resistant pathogens (Javeria et al., 2013). Methanol extract of macrolichens namely $R$. hossei, Heterodermia diademata, Roccella montagnei and Leptogium burnetiae inhibited clinical isolates of $S$. aureus and Streptococcus mutans (Kambar et al., 2014b). The study of Vivek et al. (2014a) showed the inhibitory effect of three Parmotrema species against Gram positive and Gram negative bacteria. Similarly, studies by Karthikaidevi et al. (2009), Karagöz et al. (2009), Ranković et al. (2010), Paudel et al. (2012), Pavithra et al. (2013), Kekuda (2014), Kambar et al. (2014a) and Anjali et al. (2015) showed the antimicrobial efficacy of lichens.

Table 2: Antibacterial activity of extracts of selected lichens

\begin{tabular}{lccccccc}
\hline \multirow{2}{*}{ Test bacteria } & \multicolumn{9}{c}{ Zone of inhibition in cm } \\
\cline { 2 - 7 } & P.reticulatum & H.obscurata & R.pacifica & D.consimilis & R.hossei & Antibiotic & DMSO \\
\hline S. aureus & 1.7 & 2.1 & 2.0 & 2.3 & 2.3 & 3.2 & 0.0 \\
B. subtilis & 1.8 & 1.8 & 2.2 & 2.2 & 2.2 & 3.0 & 0.0 \\
B. coagulans & 1.6 & 2.2 & 2.3 & 2.3 & 2.2 & 2.8 & 0.0 \\
K. pneumoniae & 2.1 & 2.3 & 3.2 & 2.6 & 2.6 & 2.8 & 0.0 \\
S. typhi & 1.8 & 2.0 & 2.4 & 2.4 & 2.2 & 2.6 & 0.0 \\
P. aeruginosa & 1.8 & 2.0 & 2.5 & 2.5 & 2.3 & 2.8 & 0.0 \\
E. coli & 1.7 & 1.9 & 2.1 & 2.2 & 2.0 & 2.7 & 0.0 \\
R. solanacearum & 1.8 & 1.8 & 2.0 & 2.3 & 2.0 & 2.4 & 0.0 \\
\hline
\end{tabular}
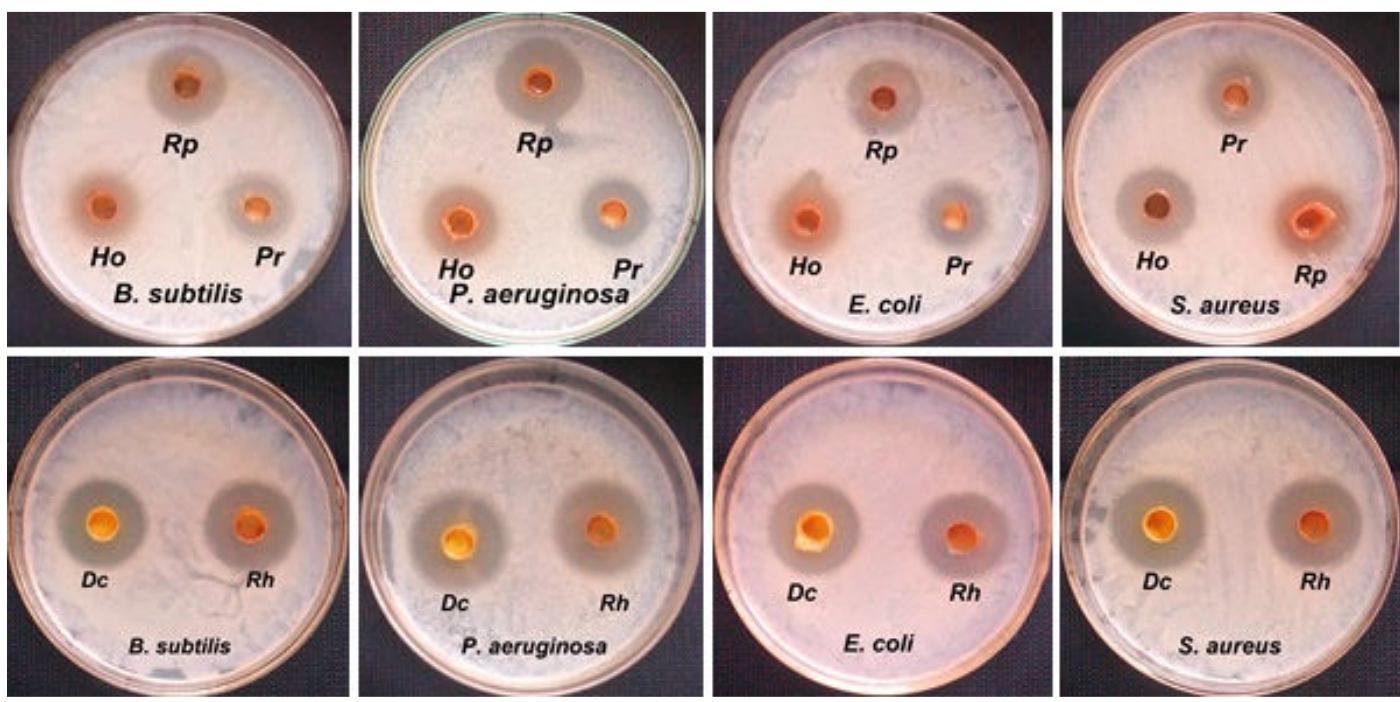

Figure 1: Inhibition of bacteria by lichens (Rp- R.pacifica; Ho- H.obscurata; Dc- D.consimilis; Pr- P.reticulatum; RhR.hossei)

\section{Antifungal Activity of Lichen Extracts}

Plants are susceptible to infections caused by many pathogens such as bacteria, viruses, nematodes and fungi. Among the various aetiological agents causing plant diseases, fungi appear to be the major pathogens causing a great number of diseases leading to enormous quantity of loss in agricultural and horticultural crops. The fungal diseases results in considerable loss of crop yield (in many cases $50 \%$ or higher). These pre- and post-harvest losses are greater in developing countries. Moreover, certain fungi are known to produce toxins (for example
Aflatoxins) which cause adverse health effects on consumption. In order to counteract the fungal diseases, chemical fungicides are widely used. The use of these chemicals is associated with certain drawbacks such as resistance development in fungi, high cost and adverse effects on non-target organisms (including humans). Natural products including extracts and purified metabolites from lichens are considered to be alternative strategies for prevention and control of fungal diseases (Wei et al., 2008; Park et al., 2008; Shukla et al., 2011; Goel et al., 2011; Kambar et al., 2014a). 


\section{Prashith Kekuda et alo,}

In the present study, we evaluated inhibitory efficacy of selected lichens by Poisoned food technique which is one of the widely used methods to evaluate the potential of various kinds of samples to inhibit the growth of fungi. Table 3 and Figure 2-4 shows the result of potential of lichen extracts to inhibit test fungi. Overall, C. capsici was inhibited to higher extent among test fungi by lichen extracts (with $>50 \%$ inhibition). $C$. capsici and $F$. oxysporum were inhibited to higher extent by $R$. pacifica. $D$. consimilis inhibited $A$. alternata to higher extent. Extract of $R$. hossei and $D$. consimilis inhibited $A$. flavus to high extent when compared to other lichens. Among lichens, $P$. reticulatum was found to inhibit test fungi to least extent. It has been shown that lichen extract exhibit inhibitory efficacy against a variety of phytopathogenic fungi. Vivek et al. (2014b) found antifungal effect of extract of three Parmotrema species against Sclerotium
Sci. Technol. Arts Res. J., July-Sep 2015, 4(3): 169-174

rolfsii (isolate from foot rot of finger millet) and Helminthosporium sp., Alternaria sp., and Aspergillus flavus isolated from moldy grains of sorghum. In a study by Kambar et al. (2014a) and Kekuda et al. (2014), marked inhibition of Colletotrichum capsici was exhibited by extracts of macrolichens. Vinayaka et al. (2014) showed the potential of extract of Usnea pictoides to inhibit the mycelial growth of $F$. oxysporum f.sp. zingiberi and Pythium aphanidermatum isolated from rhizome rot of ginger. Shivanna and Garampalli (2015) evaluated antifungal efficacy of methanol and ethyl acetate extracts of certain lichens and found their inhibitory effect against Fusarium solani causing rhizome rot of ginger. The studies by Madamombe and Afolayan (2003), Rankovic et al. (2009), Tiwari et al. (2011), Karabulut and Ozturk (2015), Devi et al. (2015) and Babiah et al. (2015) also highlighted the potential of lichens to inhibit various fungi.

Table 3: Colony diameter of fungi on control and poisoned plates

\begin{tabular}{lcccc}
\hline \multirow{2}{*}{ Treatment } & \multicolumn{4}{c}{ Colony diameter in cm (inhibition of growth in \%) } \\
\cline { 2 - 5 } & C. capsici & A. alternata & F. oxysporum & A. flavus \\
\hline Control & 4.0 & 3.8 & 4.6 & 3.3 \\
P. reticulatum & $1.8(55.00)$ & $2.8(26.31)$ & $2.8(39.13)$ & $2.4(27.27)$ \\
H. obscurata & $0.8(80.00)$ & $1.1(71.05)$ & $2.1(54.34)$ & $2.1(36.36)$ \\
R. pacifica & $0.7(82.50)$ & $2.2(42.10)$ & $1.9(58.69)$ & $1.6(51.51)$ \\
D. consimilis & $1.2(70.00)$ & $1.0(73.68)$ & $2.0(56.52)$ & $1.2(63.63)$ \\
R. hossei & $1.2(70.00)$ & $1.6(57.89)$ & $2.3(50.00)$ & $1.2(63.63)$ \\
\hline
\end{tabular}
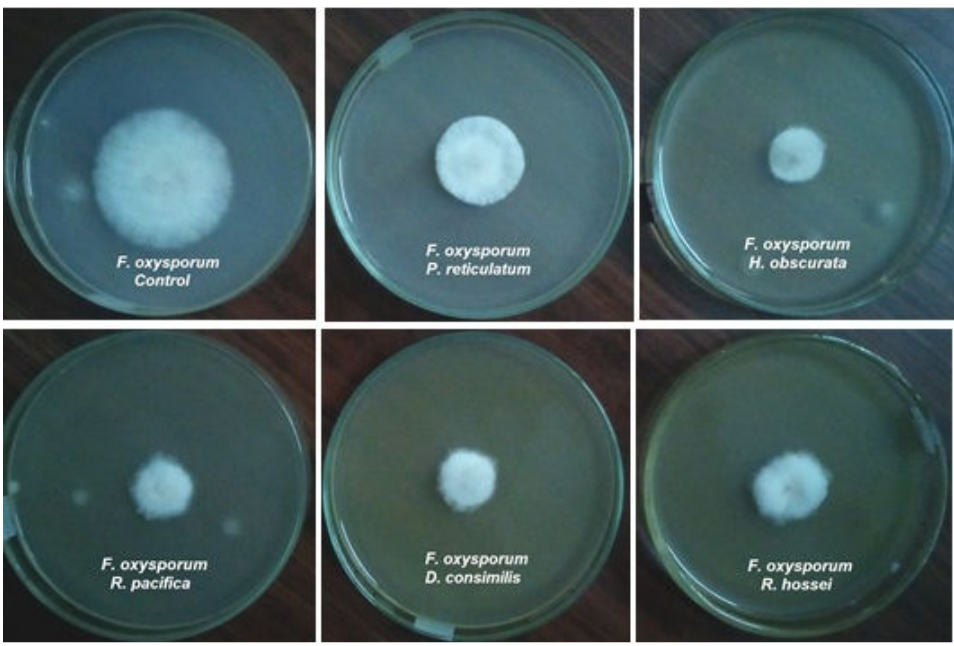

Figure 2: Inhibitory activity of lichen extracts against $F$. oxysporum
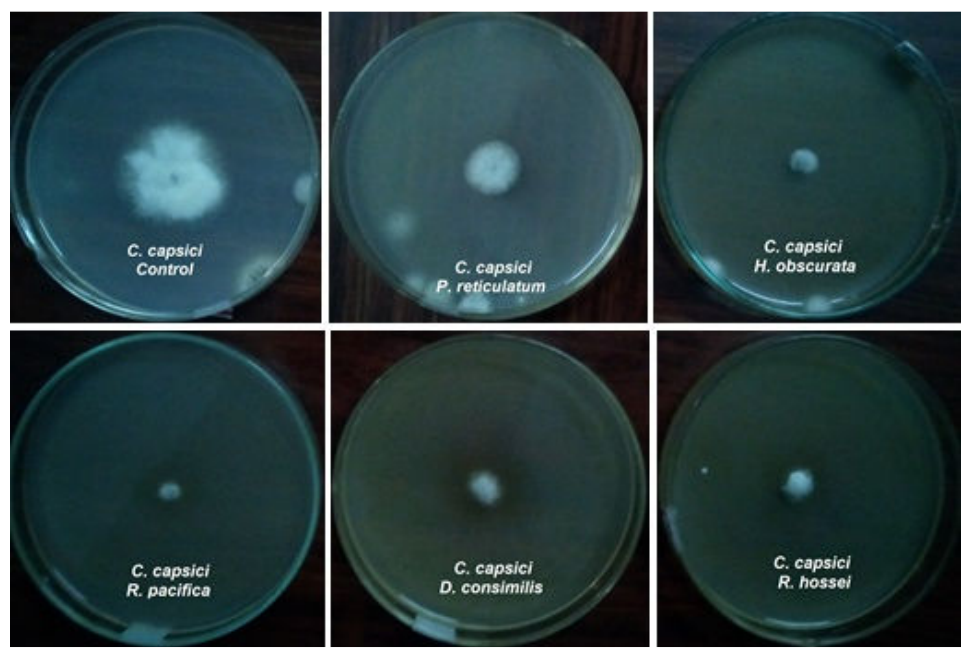

Figure 3: Inhibitory activity of lichen extracts against C. capsici 
Prashith Kekuda et alo,

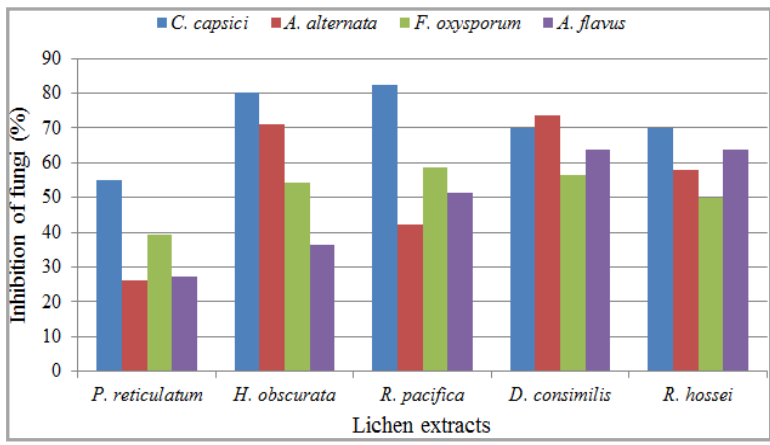

Figure 4: Inhibition (\%) of test fungi by extract of selected lichens

\section{CONCLUSION}

The lichens of the present study appear to be promising sources of bioactive compounds with potent antimicrobial activity. The observed bioactivities could be ascribed to the presence of bioactive lichen substances which are to be isolated and tested for inhibitory activity. The bioactive agents from these lichens could be used as natural antimicrobial agents and these lichens may be used to develop new therapeutic agents effective against infectious microorganisms.

\section{Conflict of Interest}

Conflict of interest none declared.

\section{Acknowledgements}

Authors thank HOD, Department of Microbiology and Principal, S.R.N.M.N College of Applied Sciences for providing the facilities. Authors also thank NES for the support.

\section{REFERENCES}

Anjali, D.B., Mohabe, S., Reddy, A.M., Nayaka, S. (2015). Antimicrobial activities of 2-Propanol crude extract from lichen Parmotrema tinctorum (Despr.ex. Nyl.) Hale, collected from Eastern Ghats, India. Current Research in Environmental and Applied Mycology 5(3): 160-168.

Awasthi, D.D. (2000). A compendium of the macrolichens from India, Nepal and Sri Lanka. Bishen Singh Mahendra Pal Singh, Dehradun, India.

Babiah, P.S., Upreti, D.K., John, S.A. (2015). Assessment of fungicidal potential of lichen Heterodermia leucomelos (L.) Poelt against pathogenic fungi. Current Research in Environmental \& Applied Mycology 5 (2): 92-100.

Balaji, P., Hariharan, G.N. (2013). Diversity of macrolichens in Bolampatti II forest range (Siruvani hills), Western Ghats, Tamil Nadu, India. ISRN Biodiversity 2013: 1-7, Article ID 124020. http://dx.doi.org/10.1155/2013/124020.

Chait, R., Vetsigian, K., Kishony, R. (2012). What counters antibiotic resistance in nature? Nature Chemical Biology 8: 2-5.

Chaves, T.P., Clementino, E.L.C., Felismino, D.C., Alves, R.R.N., Vasconcellos, A., Coutinho, H.D.M., Medeiros, A.C.D. (2015). Antibiotic resistance modulation by natural products obtained from Nasutitermes corniger (Motschulsky, 1855) and its nest. Saudi Journal of Biological Sciences 22(4): 404-408.

Culberson, C.F. (1972). Improved conditions and new data for the identification of lichen products by a standardized
Sci. Technol. Arts Res. J., July-Sep 2015, 4(3): 169-174

thin layer chromatographic method. Journal of Chromatography 72: 113-125.

Culberson, C.F., Kristinsson, H. (1970). A standardized method for the identification of lichen products. Journal of Chromatography 46: 85-93.

Devi, A.B., Mohabe, S., Reddy, M.A., Nayaka, S. (2015). Efficacy of a potential lichen Parmotrema andinum (Müll. Arg.) Hale against pathogenic microorganisms. Journal on New Biological Reports 4(2): 149-156.

Dudani, S.N., Nayaka, S., Mahesh, M.K., Chandran, S.M.D. Ramachandra, T.V. (2015). Lichen diversity in the sacred forest fragments of central Western Ghats. Journal of Biodiversity Management and Forestry 4:2.

Ghate, N.B., Chaudhuri, D., Sarkar, R., Sajem, A.L., Panja, S., Rout, J., Mandal, N. (2013). An antioxidant extract of tropical lichen, Parmotrema reticulatum, induces cell cycle arrest and apoptosis in breast carcinoma cell line MCF-7. PLoS One 2013; 8(12): e82293.

Goel, M., Sharma, P.K., Dureja, P., Rani, A., Uniyal, P.L. (2011). Antifungal activity of extracts of the lichens Parmelia reticulata, Ramalina roesleri, Usnea longissima and Stereocaulon himalayense. Archives of Phytopathology and Plant Protection 44(13): 1300-1311.

Hoskeri, J.H., Krishna, V., Amruthavalli, C. (2010). Effects of extracts from lichen Ramalina pacifica against clinically infectious bacteria. Researcher 2(3): 81-85.

Ingolfsdottir, K., Hjalmarsdottir, H.A., Sigurdsson, A., Gudjonsdottir, G.A., Brynjolfsdottir, A., Steingrimsson, O. (1997). In vitro susceptibility of Helicobacter pylori to protolichesterinic acid from the lichen Cetraria islandica. Antimicrobial agents and Chemotherapy 41(1): 215-217.

Javeria, S., Shahi, S.K., Shahi, M.P., Upreti, D.K. (2013) Parmotrema nilgherrense: potential antimicrobial activity against drug resistant pathogens. International Journal of Microbial Resource Technology 2(1): 36-40.

Kambar, Y., Vivek, M.N., Manasa, M., Kekuda, P.T.R., Onkarappa, R. (2014a). Antimicrobial activity of Ramalina conduplicans Vain. (Ramalinaceae). Science, Technology and Arts Research Journal 3(3): 57-62.

Kambar, Y., Vivek, M.N., Manasa, M., Vinayaka, K.S., Mallikarjun, N, Kekuda, P.T.R. (2014b). Antimicrobial activity of Leptogium burnetiae, Ramalina hossei, Roccella montagnei and Heterodermia diademata. International Journal of Pharmaceutical and Phytopharmacological Research 4(3): 164-168.

Karabulut, G., Ozturk, S. (2015). Antifungal activity of Evernia prunastri, Parmelia sulcata, Pseudevernia furfuracea var. furfuracea. Pakistan Journal of Botany 47(4): 1575-1579.

Karagöz, A., Doguöz, N., Zeybek, Z., Aslan, A. (2009). Antibacterial activity of some lichen extracts. Journal of Medicinal Plants Research 3(12): 1034-1039.

Karthikaidevi, G., Thirumaran, G., Manivannan, K., Anantharaman, P., Kathiresan, K., Balasubaramanian, T. (2009). Screening of the antibacterial properties of lichen Roccella belangeriana (Awasthi) from Pichavaram mangrove (Rhizophora sp.). Advances in Biological Research 3(3-4): 127-131.

Kekuda, P.T.R. (2014). Inhibitory activity of Usnea pictoides G. Awasthi (Parmeliaceae) against urinary tract isolates. Scholars Academic Journal of Biosciences 2(8): 561-563.

Kekuda, P.T.R., Raghavendra, H.L., Swathi, D., Venugopal, T.M., Vinayaka, K.S. (2012). Antifungal and cytotoxic 
Prashith Kekuda et al.,

activity of Everniastrum cirrhatum (Fr.) Hale. Chiang Mai Journal of Science 39(1): 76-83.

Kekuda, P.T.R., Vivek, M.N., Kambar, Y., Manasa, M. (2014). Biocontrol potential of Parmotrema species against Colletotrichum capsici isolated from anthracnose of chilli. Journal of Biological and Scientific Opinion 2(2): 166-169.

Madamombe, I.T., Afolayan, A.J. (2003). Evaluation of antimicrobial activity of extracts from South African Usnea barbata. Pharmaceutical Biology 41(3): 199-202.

Nayaka, S., Upreti, D.K., Saxena, S. (2007). Muscicolous lichens of Indian subcontinent. In: Current Trends in Bryology. Nath, V., Asthana, A.K. (Editors). Bishen Singh Mahendra Pal Singh, Dehra Dun, India. pp 245-254.

Nayaka, S., Upreti, D.K., Phatak, S., Samuel, C. (2006). Preliminary observation of lichen flora of coconut and areca nut orchards of Goa, India. Phytotaxonomy 6:2325.

Park, I., Kim, J., Lee, Y., Shin, S. (2008). In vivo fungicidal activity of medicinal plant extracts against six phytopathogenic fungi. International Journal of Pest Management 54(1): 63-68.

Paudel, B., Bhattarai, H.D., Pandey, D.P., Hur, J.S., Hong, S.G., Kim, I., Yim, J.H. (2012). Antioxidant, antibacterial activity and brine shrimp toxicity test of some mountainous lichens from Nepal. Biological Research 45(4): 387-391.

Pavithra, G.M., Vinayaka, K.S., Rakesh, K.N., Junaid, S., Dileep, N., Kekuda, P.T.R, Siddiqua, S., Naik, A.S. (2013). Antimicrobial and antioxidant activities of a macrolichen Usnea pictoides G. Awasthi (Parmeliaceae). Journal of Applied Pharmaceutical Science 3(8): 154-160.

Rambo, T.R. (2010). Structure and composition of corticolous epiphyte communities in a Sierra Nevada old-growth mixed-conifer forest. The Bryologist 113(1): 55-71.

Rankovic, B., Mišic, M., Sukdolak, S. (2009). Antimicrobial activity of extracts of the lichens Cladonia furcata, Parmelia caperata, Parmelia pertusa, Hypogymnia physodes and Umbilicaria polyphylla. Biologia 64: 53-58.

Ranković, B., Ranković, D., Marić, D. (2010). Antioxidant and antimicrobial activity of some lichen species. Mikrobiologiia 79(6): 812-818.

Rout, J., Singha, B.A., Upreti, D.K. (2012). Lichen flora on betel nut (Areca catechu) palm tree from a pristine habitat in Southern Assam, India. Vegetos: An International Journal of Plant Research 25(1): 198-201.

Shivanna, R., Garampalli, R.H. (2015). Evaluation of fungistatic potential of lichen extracts against Fusarium solani (Mart.) Sacc. causing rhizome rot disease in Ginger. Journal of Applied Pharmaceutical Science 5 (10): 67-72.

Shukla, A.C., Chinlampianga, M., Verma, A., Dikshit, A., Upreti, D.K. (2011). Efficacy and potency of lichens of Mizoram as antimycotic agents. Indian Phytopathology 64 (4): 367-370.

Shukla, P., Upreti, D.K., Nayaka, S., Tiwari, P. (2014). Natural dyes from Himalayan lichens. Indian Journal of Traditional Knowledge 13(1): 195-201.

Swathi, D., Suchitha, Y., Kekuda, P.T.R., Venugopal, T.M., Vinayaka, K.S., Mallikarjun, N., Raghavendra, H.L. (2010). Antimicrobial, anthelmintic and insecticidal activity of a macrolichen Everniastrum cirrhatum (Fr.) Hale. International Journal of Drug Development and Research 2(4): 780-789.
Sci. Technol. Arts Res. J., July-Sep 2015, 4(3): 169-174

Tiwari, P., Rai, H., Upreti, D.K., Trivedi, S., Shukla, P. (2011). Antifungal activity of a common Himalayan foliose lichen Parmotrema tinctorum ( Despr. ex Nyl.) Hale. Nature and Science 9(9): 167-171.

Turk, A.O., Yılmaz, M., Kivan, M., Turk, H. (2003). The antimicrobial activity of extracts of the lichen Cetraria aculeata and its protolichesterinic acid constituent. Zeitschrift fur Naturforschung 58c: 850-854.

Turk, H., Yılmaz, M., Tay, T., Turk, A.O., Kıvanc, M. (2006). Antimicrobial activity of extracts of chemical races of the lichen Pseudevernia furfuracea and their physodic acid, chloroatranorin, atranorin, and olivetoric acid constituents. Zeitschrift fur Naturforschung 61c: 499-507.

Upreti, D.K., Bajpai, R., Nayaka, S. (2013). Ethnobotanically important Indian lichens. Ethnobotany 25: 33-40.

Upreti, D.K., Nayaka, S. (2008). Need for creation of lichen gardens and sanctuaries in India. Current Science 94(8): 976-978.

Verma, N., Behera, B.C., Parizadeh, H., Sharma, B.O. (2011). Bactericidal activity of some lichen secondary compounds of Cladonia ochrochlora, Parmotrema nilgherrensis and Parmotrema sancti-angelii. International Journal of Drug Development and Research 3(3):222232.

Verma, N., Behera, B.C., Sharma, B.O. (2012). Glucosidase inhibitory and radical scavenging properties of lichen metabolites salazinic acid, sekikaic acid and usnic acid Hacettepe Journal of Biology and Chemistry 40 (1): 7-21.

Vinayaka, K.S., Kekuda, P.T.R., Nawaz, N.A.S., Junaid, S., Dileep, N., Rakesh, K.N. (2014). Inhibitory activity of Usnea pictoides G.Awasthi (Parmeliaceae) against Fusarium oxysporum f.sp. zingiberi and Pythium aphanidermatum isolated from rhizome rot of ginger. Life Sciences Leaflets 49: 17-22.

Vinayaka, K.S., Krishnamurthy, Y.L., Kekuda, P.T.R., Kumar, P.S.V., Sudharshan, S.J., Chinmaya, A. (2009). Larvicidal and wormicidal efficacy of methanolic extracts of five macrolichens collected from Bhadra wildlife sanctuary. Biomedicine 29(4): 327-331.

Vivek, M.N., Kambar, Y., Manasa, M., Kekuda, P.T.R., Vinayaka, K.S. (2014a). Radical scavenging and antibacterial activity of three Parmotrema species from Western Ghats of Karnataka, India. Journal of Applied Pharmaceutical Science 4(3): 86-91.

Vivek, M.N., Manasa, M., Kambar, Y., Kekuda, P.T.R., Raghavendra, H.L. (2014b). Antifungal efficacy of three bioactive Parmotrema species from Western Ghats of Karnataka, India. International Journal of Agriculture and Crop Sciences 7(12): 968-973.

Walker, F.J., James, P.W. (1980). A revised guide to microchemical techniques for the identification of lichen substances. Bulletin of British Lichenological Society 46 (Supp I): 13-29.

Wei, X., Jeon, H., Han, K.S., Koh, Y.J., Hur, J. (2008). Antifungal activity of lichen-forming fungi against Colletotrichum acutatum on hot pepper. The Plant Pathology Journal 24(2): 202-206.

Yilmaz, M., Turk, A.O., Tay, T., Kıvanc, M. (2004). The antimicrobial activity of extracts of the lichen Cladonia foliacea and its (-)-usnic acid, atranorin, and fumarprotocetraric acid constituents. Zeitschrift fur Naturforschung 59c: 249-254

Zambare, V.P., Christopher, L.P. (2012). Biopharmaceutical potential of lichens. Pharmaceutical Biology 50(6):778-98. 